\title{
Single Subcutaneous Administration of Chorionic Gonadotropin to Rats Induces a Rapid and Transient Increase in Testicular Expression of Pro-Inflammatory Cytokines
}

\author{
MONIQUE ASSMUS, KONSTANTIN SVECHNIKOV, MIKAEL VON EULER, BRIAN SETCHELL, \\ TARANUM SULTANA, CECILIA ZETTERSTRÖM, MIKAEL HOLST, WIELAND KIESS, AND \\ OLLE SÖDER \\ Pediatric Endocrinology Unit, Department of Woman and Child Health [M.A., K.S., M.v.E., B.S., T.S., \\ C.Z., M.H., O.S.], Astrid Lindgren Children's Hospital, Karolinska Institute and University Hospital, \\ Stockholm, Sweden; Children's Hospital, Department of Pediatrics [M.A., W.K.], University of Leipzig, \\ Germany; Department of Anatomical Sciences [B.S.], University of Adelaide, Australia; Department of \\ Biological and Biomedical Sciences [T.S.], The Aga Khan University, Karachi, Pakistan
}

\begin{abstract}
ABSTR
hCG has been reported to cause an inflammation-like effect in
the testis, although the background and consequences of this
phenomenon remain to be understood. This investigation reveals
that a single injection of hCG (100 U) induces a transient surge
in pro-inflammatory cytokine expression in the adult rat testis.
Reverse transcriptase PCR analysis demonstrated onset of testic-
ular expression of IL-1 $\beta$ and IL- 6 mRNA and increases in the
levels of mRNA encoding the constitutively expressed cytokines
IL-1 $\alpha$, IL-1 receptor antagonist, and tumor necrosis factor- $\alpha$ h
after hCG injection and a maximal response after $8-12$ h. These
increases were accompanied by a transient increase in testicular
IL-1 bioactive protein. Twenty-four hours after administration of
hCG, the levels of all cytokine mRNA had decreased, although
most were still elevated above control. Immunohistochemical
staining revealed that the IL- $1 \beta$ protein was undetectable in
normal testes but was seen to be localized to interstitial macro-
phages but not Leydig cells after hCG treatment. Testes devoid
of Leydig cells after pretreatment with ethane dimethane sulpho-
nate exhibited normal staining for interstitial macrophages but
\end{abstract}
Human chorionic gonadotropin (hCG) shares receptors with luteinizing hormone (LH) and is used clinically in high pharmacological doses to stimulate testicular descent in boys with cryptorchidism. This treatment is known to induce acute in-

Received June 4, 2004; accepted October 13, 2004

Correspondence: Olle Söder, M.D., Ph.D., Department of Woman and Child Health, Astrid Lindgren Children's Hospital, Pediatric Endocrinology Unit, Karolinska Institute and University Hospital, Q2:08, S-17176 Stockholm, Sweden; e-mail: olle.soder@kbh.ki.se

Financial support for this study was provided by the Swedish Research Council (Project No. 8282), Frimurare Barnhuset in Stockholm, H.R.H. Crown Princess Lovisa Society of Pediatric Health Care, the Children's Cancer Found, the Swedish Natural Protection Agency, the European Union, and the Karolinska Institute.

DOI: 10.1203/01.PDR.0000161410.30145.15 failed to respond to hCG with increases in IL- $1 \beta$ mRNA and protein expression. We conclude that hCG induces testicular inflammation via local activation by Leydig cells of the production of pro-inflammatory cytokines by resident macrophages. It remains to be investigated whether the high-dose hCG regimens used for treatment of boys with cryptorchidism could induce similar increases of pro-inflammatory cytokines in the human testis and if such treatments could adversely affect future testicular function. (Pediatr Res 57: 896-901, 2005)

$\quad$ Abbreviations
EDS, ethane dimethane sulphonate
G3PDH, glycerol-3-phosphate dehydrogenase
hCG, human chorionic gonadotrophin
IL-1ra, interleukin-1 receptor antagonist
Mr, relative molecular mass
RT-PCR, reverse transcriptase polymerase chain reaction
TNF $\boldsymbol{\alpha}$, tumor necrosis factor- $\alpha$
$\mathbf{3 \beta} \boldsymbol{\beta}$-HSD, $3 \beta$-hydroxy steroid dehydrogenase

flammation-like effects in the testis and it has been speculated that this may have adverse consequences for adult testicular function (1-8). Testicular inflammation has also been observed following systemic exposure to endotoxin and found to involve intratesticular expression of pro-inflammatory cytokines, such as interleukin (IL)-1 $\beta$ and IL-6 (9). Furthermore, it has been found previously that local injection of IL- $1 \beta$ but not of IL- $1 \alpha$ into the testis results in a vascular inflammatory response similar to that induced by high doses of hCG (10) and that pretreatment with hCG seems to increase the sensitivity of the testis to the local pro-inflammatory action of IL-1 (4).

Several pro-inflammatory cytokines, most notably IL- $1 \alpha$, IL-1 receptor antagonist (IL-1ra) and tumor necrosis factor 
(TNF)- $\alpha$, are produced constitutively by the adult rat testis. Both the constitutively produced and the inflammation-induced cytokines have been proposed to function as physiologic and pathophysiological paracrine mediators in the testis (for recent reviews, see references 11,12 ). Interestingly, the testis actually produces and secretes several bioactive isoforms of IL- $1 \alpha$, including a newly discovered variant formed by alternate splicing $(13,14)$.

The source of these constitutive cytokines is believed to be primarily nonimmune cells, such as Sertoli and germ cells; whereas induction of cytokines such as IL- $1 \beta$ involves activation of resident testicular macrophages by various stimuli $(9,15-17)$.

The aim of the present study was to identify paracrine mediators involved in the proinflammatory action of hCG in the testis. Specifically, we examined the effects of administration of a single, high, systemic dose of hCG to rats on testicular levels of different cytokine mRNAs and proteins.

\section{MATERIALS AND METHODS}

Animals and treatment. Male Sprague-Dawley rats (BK Laboratories, Sollentuna, Sweden) $60 \mathrm{~d}$ old were housed in standard cages under controlled conditions at the animal facilities of the university. These animals received a single s.c. injection of 100 units of hCG (SIGMA, St. Louis, MO, USA) in 0.5 $\mathrm{mL}$ isotonic saline or the same volume of saline as control. This dose of hCG was found to produce maximal testicular inflammation in preceding experiments (unpublished observations). For RT-PCR and hormonal analyses, whole testes were collected and blood samples taken from the inferior vena cava and testicular vein with a micropipette from three animals after $0,4,8,12,16$ and $24 \mathrm{~h}$ following the injection. In another set of experiments, the testes from 4-6 animals in each group were collected before and every three hours for the first day following injection of hCG for protein extraction. In yet another set of experiments four rats were treated s.c. with ethane dimethane sulphonate (EDS; $75 \mathrm{mg} / \mathrm{kg}$ body weight, dissolved in DMSO:water 1:2) or equally many control animals with solvent alone. Three days later, these rats were administered $100 \mathrm{U}$ hCG or saline and testes and blood samples collected, $8 \mathrm{~h}$ after this treatment, as described above. This time point after treatment with EDS produces maximal Leydig cell destruction and no recovery is yet evident (18). The testes were weighed, decapsulated, cut into pieces and frozen immediately at $-80^{\circ} \mathrm{C}$ for storage until further analysis. The blood samples were centrifuged at $13,000 \mathrm{rpm}$ for $15 \mathrm{~min}$. to obtain sera, which were also immediately frozen at $-80^{\circ} \mathrm{C}$.

Preparation of RNA and RT-PCR analysis. Total RNA was prepared from testes by employing the Ultraspec II Kit (BIOTECX Laboratories, Houston, TX, USA) according to the manufacturer's protocol, except for the EDStreated rats and their controls from which testis RNA was isolated using TRIZOL Reagent (LIFE TECHNOLOGIES, Inc., Rockville, M.D., USA) according to the manufacturer's instructions. One $\mu \mathrm{g}$ of the total RNA thus obtained was used for RT-PCR. Complementary DNAs were synthesized utilizing $300 \mathrm{U}$ reverse transcriptase

(SUPERSCRIPT TM, LIFE TECHNOLOGIES, Inc., Rockville, M.D., USA), $3 \mu \mathrm{L} 5 \mathrm{mM}$ specific reverse primer for each cytokine (Table 1), $1 \mu \mathrm{L}$ of a mixture of $10 \mathrm{mM}$ dNTPs (AMERSHAM PHARMACIA Biotech Inc, Princeton, NJ, USA), $4 \mu \mathrm{L}$ 5-fold concentrated first strand buffer $(250 \mathrm{mM}$, LIFE TECHNOLOGIES, Inc.), $2 \mu \mathrm{L} 0,1 \mathrm{mM}$ DTT (LIFE TECHNOLOGIES,
Inc.) and 60U RNase Inhibitor (BOEHRINGER-MANNHEIM, Mannheim, Germany) in a final volume of $20 \mu \mathrm{L}$ at $45^{\circ} \mathrm{C}$ for $2 \mathrm{~h}$. Thereafter, $10 \mu \mathrm{L}$ of the resulting reaction mixture, $5 \mu \mathrm{L} 5 \mathrm{mM}$ upstream and downstream primers (Table 1), 1.75U High Fidelity Enzyme Mix (BOEHRINGER-MANNHEIM) and $5 \mu \mathrm{L}$ 10-fold concentrated Expand High Fidelity Buffer containing $15 \mathrm{mM}$ $\mathrm{MgCl} 2$ (BOEHRINGER-MANNHEIM) in a total volume of $50 \mu \mathrm{L}$ were used for PCR amplification on a Perkin-Elmer GeneAmp PCR System 2400. The amplification profile used was as follows: $5 \mathrm{~min}$ at $96^{\circ} \mathrm{C}$, followed by $30-35$ cycles of denaturation for $1 \mathrm{~min}$ at $94^{\circ} \mathrm{C}$, annealing for $30 \mathrm{~s}$ at $52-58^{\circ} \mathrm{C}$ (Table 1) and extension for $1 \mathrm{~min}$ at $72^{\circ} \mathrm{C}$; and, finally, $5 \mathrm{~min}$ at $72^{\circ} \mathrm{C}$ (Table 1). Twenty $\mu \mathrm{l}$ of the PCR product thus produced was subsequently electrophoresed on a $1 \%$ agarose gel containing ethidium bromide and quantitation then performed utilizing a Fluor S TM Multi Scanner (BIO RAD Laboratories, Herkules, CA) with subtraction of the background values for blanks (empty electrophoresis lane). The level of cytokine mRNA was normalized by comparison to the level of mRNA coding for glycerol-3-phosphate dehydrogenase (G3PDH), which was assumed to remain constant (Table 1).

Morphologic examination, staining for $3 \beta$-hydroxysteroid dehydrogenase activity and immunohistochemical staining for $I L-1 \beta$, and ED2. Frozen testicular tissue was cut into $10 \mu \mathrm{m}$ thick slices and these sections were subsequently attached to slides (Superfrost plus, Menzel-Gläser, KEBO Laboratories, Stockholm, Sweden) by momentary thawing. After drying for $30 \mathrm{~min}$ at room temperature, the Leydig cells on the slides thus obtained were identified by demonstrating the presence of $3 \beta$-hydroxysteroid dehydrogenase $(3 \beta$-HSD) activity. To this end, the cells were incubated with a solution containing $0.6 \mathrm{mg}$ etiocholan- $3 \beta$-ol $17 \mathrm{one}, 1 \mathrm{mg}$ nitroblue tetrazolium, $5 \mathrm{mg}$ $\beta$-nicotinamide adenine dinucleotide and $4.8 \mathrm{~mL}$ phosphate buffer solution for one hour at $37^{\circ} \mathrm{C}$. After rinsing with ethanol, all slides were fixed for $8 \mathrm{~min}$ with $2 \%$ formaldehyde in PBS at $4^{\circ} \mathrm{C}$.

For simultaneous staining of IL- $1 \beta$ protein and ED2 antigen (a rat marker for macrophages), these same slides were incubated with $1 \mathrm{M}$ glycine (KEBO Laboratories) for $30 \mathrm{~min}$ at $4{ }^{\circ} \mathrm{C}$ and subsequently blocked with $1 \% \mathrm{BSA}$ and $0.1 \%$ saponine (SIGMA, St. Louis, MO, USA) before incubation overnight at $4^{\circ} \mathrm{C}$ with primary polyclonal goat anti-rat IL-1 $\beta$ antibodies, diluted 1:20 (R\&D Systems, Minneapolis, MN, USA), and with polyclonal mouse anti-rat macrophage antibodies (ED 2), diluted 1:400 (SEROTEC, Oxford, UK). The following day the slides were rinsed with PBS containing 1\% BSA and $0.1 \%$ saponin and thereafter incubated with secondary FITC-conjugated donkey anti-goat antibodies, diluted 1:200 (JACKSON Immuno Research Lab, Inc., West Grove, PA, USA), and with Gy3-conjugated donkey-anti mouse antibodies, diluted 1:50 (JACKSON Immuno Research Lab), for $1 \mathrm{~h}$ at room temperature and subsequently washed with PBS and air-dried. Staining for Leydig cells ( $3 \beta$-HSD activity), macrophages (ED 2 ) and IL-1 $\beta$ was finally examined by light (the former) and fluorescent (the latter two) microscopy (NIKON, Bergstrom Inst., Solna, Sweden).

Overall testicular histology was examined after staining of sections with Crysyl violet. The lymphocytes (identified on the basis of their morphologic appearance, including size and nuclear shape) and ED 2-positive macrophages, detected as above, present in 15 randomly chosen fields per testis $(n=3)$ defined by an ocular grid, were counted under the light microscope.

Preparation and culture of Leydig cells. Leydig cells were isolated from testes of 80-d-old rats by enzymatic digestion and Percoll gradient centrifugation as described previously (19). Purified Leydig cells ( $>85 \%$ positive for $3 \beta$-HSD) were incubated for 3 and $24 \mathrm{~h}$ in the presence or absence of hCG (10 $\mathrm{ng} / \mathrm{mL}$ ) and RNA prepared thereafter as described (19). Quantitation of the mRNA encoding IL- $1 \beta$ and the house-keeping gene G3PDH was performed as described above.

Preparation of testis protein and murine thymocyte IL-1 bioassay. Testes were collected from hCG-treated and control rats for extraction of protein and determination of the bioactivity of IL-1. These testes (from 4-6 rats per group) were homogenized in isotonic saline, centrifuged in a series of steps and passed

Table 1. Sequences of the upstream and downstream primers together with the RT-PCR conditions employed for synthesizing cDNA

\begin{tabular}{|c|c|c|c|c|c|}
\hline Product & Sequence of the upstream primer & Sequence of the downstream primer & $\begin{array}{c}\text { PCR } \\
\text { product } \\
\text { size (bp) }\end{array}$ & $\begin{array}{c}\text { Annealing } \\
\text { temperature } \\
\left({ }^{\circ} \mathrm{C}\right)\end{array}$ & $\begin{array}{l}\text { PCR } \\
\text { cycles }\end{array}$ \\
\hline IL- $1 \alpha \& 24$ KproIL- $1 \alpha$ & GACCATCTGTCTCTGAATCAG & CGATGAGTAGGCATACATGTC & $453 \& 283$ & 58 & 30 \\
\hline IL-1ra & GGGATACTAACCAGAAGACCT & AGCGCTTGTCTTCTTCTTTGT & 247 & 52 & 35 \\
\hline IL-6 & GAAATACAAAGAATTAAGAC & GTGTTTCAACATTCATATATTGC & 487 & 52 & 35 \\
\hline $\mathrm{TNF} \alpha$ & GAGATGTGGAACTGGCACA & CTTGAAGAGAACCTGGGAGTA & 409 & 53 & 30 \\
\hline
\end{tabular}


through a PD-column to collect material with $\mathrm{Mr}>5 \mathrm{~K}$, as described previously in detail $(20,21)$.

The protein concentration of the fractions thus obtained was determined by the procedure of Bradford and adjusted to $4 \mathrm{mg}$ per $\mathrm{ml}$ by addition of culture medium. The testis protein extracted in this manner was analyzed for IL-1 bioactivity in a bioassay based on thymocytes from NMRI/KI mice, which are highly sensitive to IL-1 (20). For control testes obtained from untreated rats, a final protein concentration of $6 \mu \mathrm{g}$ per $\mathrm{ml}$ culture medium was found to be within the linear part of the dose-response curve and to produce approximately $30 \%$ of the maximal response. Therefore, the IL-1 bioactivity of all testis extracts was based of analyses of this concentration of testicular protein.

Quantitation of serum levels of testosterone. Serum samples $(50 \mu \mathrm{L})$ from systemic and testicular venous blood were used for the determination of testosterone by RIA (Coat-A-Count Total Testosterone, DPC, Los Angeles, CA, USA). The sensitivity of the assay was $0.04 \mathrm{ng} / \mathrm{mL}$ and the inter-assay and intra-assay precisions $9 \%$ and $5 \%$, respectively, at the actual levels of determination.

Statistical analyses. The results were analyzed using one-way ANOVA in the case of multiple comparisons $t$ test was used in single comparisons of two groups. A p-value of less than 0.05 was considered to be statistically significant.

Ethical considerations. The animal experimentation involved here was approved by the Northern Stockholm Animal Ethics Committee (N102/99).

\section{RESULTS}

Testicular levels of mRNA species coding for proinflammatory cytokines. Employing RT-PCR constitutive expression of mRNAs encoding IL- $1 \alpha$, splice variant 24 KproIL$1 \alpha$, IL-1ra and TNF $\alpha$ was clearly detectable in control testes and, furthermore, when normalized by comparison to the levels of the mRNA for the house-keeping gene G3PDH, slight, but significant increases in the levels of these mRNA species were observed $4-8 \mathrm{~h}$ following injection of hCG (Fig. 1). No IL-1 $\beta$ or IL-6 mRNA was detected in normal, control testes; but within $4 \mathrm{~h}$ after hCG administration, these mRNAs were readily observed (Fig. 1). Maximal levels of all of the proinflammatory cytokine mRNAs analyzed here were present $8-12 \mathrm{~h}$ after hCG injection. Subsequent decreases in the intensities of the corresponding RT-PCR signals were seen $24 \mathrm{~h}$, after such treatment, although these levels were still elevated over control values for all of the cytokines except TNF $\alpha$ (Fig. 1).

Testicular levels of bioactive IL-1 protein. As simultaneous increases of mRNAs for IL- 1 agonists (IL- $1 \alpha$, IL- $1 \beta$ ) and antagonist (IL- 1ra) were observed it was of great interest to see whether the agonist/antagonist net balance was changed at the functional (protein) level in the testis tissue by hCG. Indeed, hCG induced a transient increase in the IL-1 bioactivity produced by tissue protein from the rat testis, as assessed utilizing a murine thymocyte proliferation assay which is sensitive to both IL- $1 \alpha$, IL-1 $\beta$ and IL-1ra. The response here mirrored the time-course of the changes in mRNA levels, maximal activity being detected $9 \mathrm{~h}$ following $\mathrm{hCG}$ injection and return to the basal level being observed after $24 \mathrm{~h}$ (Fig. 2).

The responsiveness of rat testes depleted of Leydig cells to $\boldsymbol{h C G}$. The testes of rats treated with EDS, with or without subsequent administration of hCG (100U), appeared macroscopically normal. That the EDS and hCG treatments exerted the expected effects was verified by quantitation of testosterone in systemic and venous testicular blood. Following treatment with EDS, these testosterone levels were low or undetectable regardless of whether hCG was subsequently injected or not (Table 2).
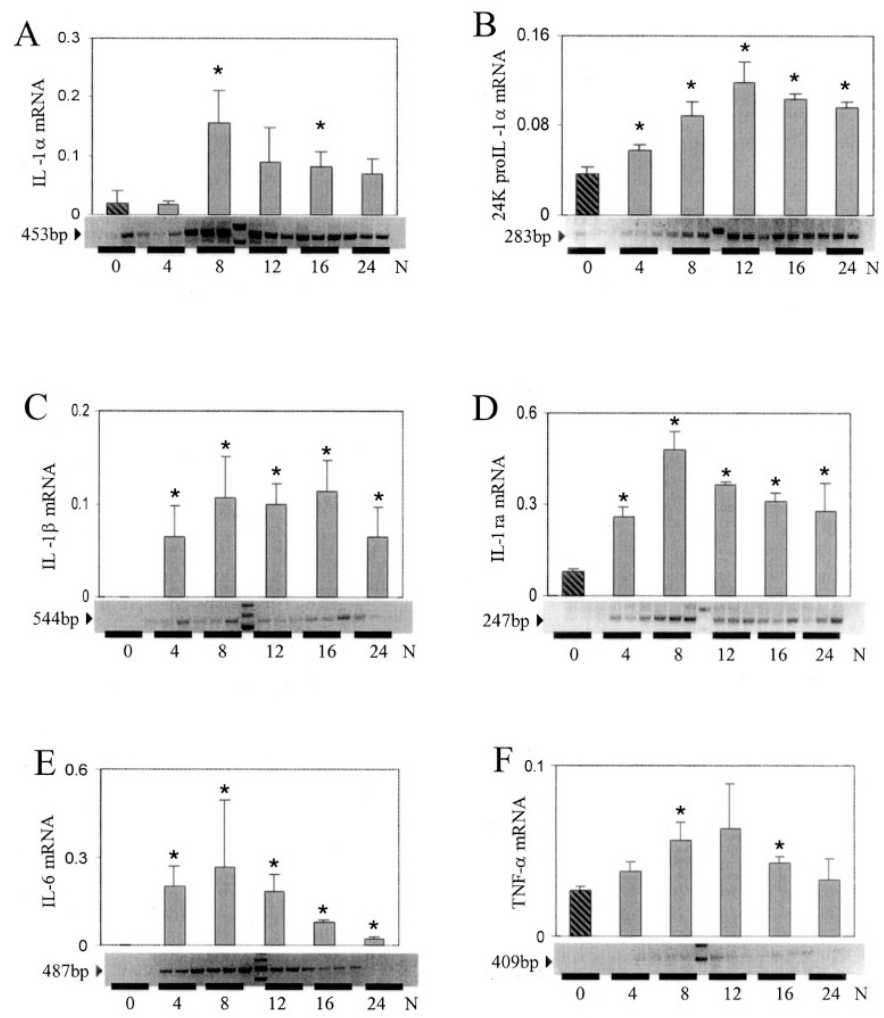

Hours after hCG treatment

Figure 1. Surges in the levels of IL-1 $\alpha(A), 24 \mathrm{KproIL}-1 \alpha(B)$, IL- $1 \beta(C)$, IL-1 ra $(D)$, IL-6 $(E)$ and TNF- $\alpha(F)$ mRNAs in testes $4-24 \mathrm{~h}$ after s.c. injection of hCG (100U) into rats. The values shown are means $\pm \mathrm{SD}(n=3)$ of arbitrary densitometry units determined following RT-PCR amplification of these mRNA species, with normalization to the level of G3PDH mRNA. Negative PCR control (N): water instead of RNA. A representative RT-PCR experiment is shown beneath each bar graph. Data were pooled from 3 bands (horizontal bar). * significant differences $(p<0.05)$ compared with the control (time 0).

In contrast to the case with control animals, hCG failed to induce IL- $1 \beta$ mRNA in the testes of EDS-treated rats, eight hours after injection (Fig. 3A). Nor did stimulation of isolated Leydig cells with hCG at a dose sufficient to cause maximal testosterone production in vitro induce any expression of IL-1 $\beta$ mRNA, as assessed by RT-PCR (Fig. 3B). As expected, Leydig cells were absent from the testes of EDS-treated rats (Fig. 4FI).

Cellular localization of the $I L-1 \beta$ protein in rat testis. Employing 3- $\beta$ HSD staining as a marker for Leydig cells and immunohistochemical double staining for IL- $1 \beta$ and macrophages (ED 2), it was evident that $8 \mathrm{~h}$ after hCG treatment of normal rats IL- $1 \beta$ was localized in the macrophages (Fig. $4 E I I-E I I I)$. This protein was undetectable in Leydig cells (Fig. $4 D, E)$. In testes depleted of Leydig cells, no IL- $1 \beta$ protein was detectable following hCG treatment (Fig. $4 F$ ), an observation which mirrors the findings on mRNA levels, both in vivo and in vitro (Figs. $3 A$ and $B$ ).

Leukocyte migration to the testis. Since hCG is known to stimulate migration of leukocytes into the testis, we compared the numbers of lymphocytes and macrophages present in rat testicular tissue prior and eight hours subsequent to administration of hCG. The number of ED2-positive cells in testes of hCG treated animals did not differ from the corresponding 


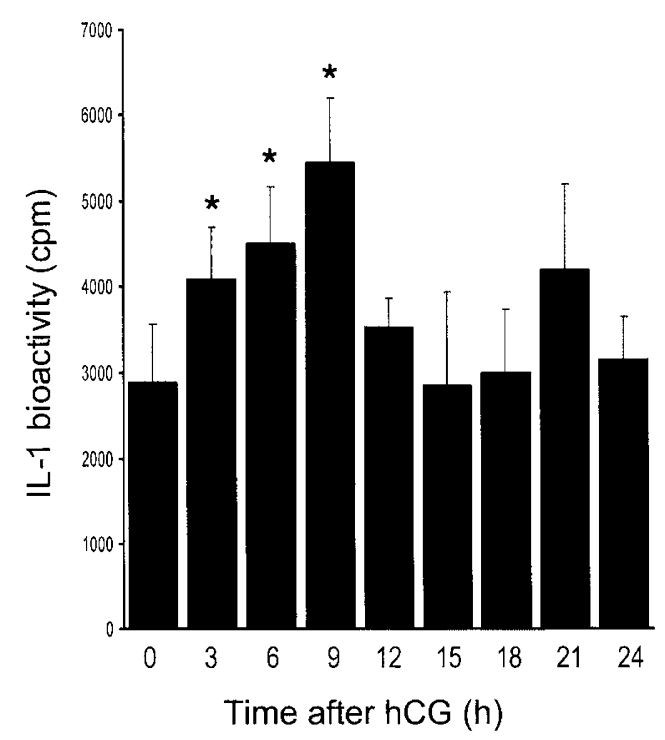

Figure 2. Transient surge in IL-1 bioactivity exerted by extracted tissue protein from testes of hCG treated rats. Testes were collected at the time-points indicated following a single s.c. administration of hCG (100U) and an extract of total testicular protein (at a concentration of $6 \mu \mathrm{g} / \mathrm{mL}$ ) assayed for IL-1 bioactivity in cultures of thymocytes isolated from highly IL-1 responsive NMRI/KI mice. The values shown are means + SD $(n=4-6)$ of the incorporation of tritiated thymidine into the DNA of these thymocytes. Background incubations in the presence of medium alone gave a value of $550 \mathrm{cpm}$. * significant differences $(p<0.05)$ compared with the control (time 0$)$.

number in control animals $(35.7 \pm 2.1$ versus. $33.7 \pm 2.56$ (mean $\pm \mathrm{SE} ; n=3$; data from 15 randomly chosen ocular grid areas per testis), $p=0.5$ ). On the other hand, the number of testicular lymphocytes (identified on the basis of their morphology under the light microscope) was significantly elevated $8 \mathrm{~h}$ after hCG treatment $(8.2 \pm 0.55$ versus $6.3 \pm 0.27$ (mean $\pm \mathrm{SE}, n=3) ; p=0.004$ ).

Serum levels of testosterone. The testosterone levels in both peripheral and testicular venous blood were significantly elevated already $2 \mathrm{~h}$ after hCG treatment (not shown; Cf. results after EDS, Table 2).

\section{DISCUSSION}

In the present investigation we demonstrate that a single, high-dose, s.c. injection of hCG induces rapid and transient increases in the levels of pro-inflammatory cytokines in the rat testis. These increases were seen both at the mRNA level (as assessed by RT-PCR) and at the level of bioactive protein as assessed by assaying the effect of extracted testicular protein on murine thymocyte proliferation. These responses involved Leydig cells, since they did not occur in EDS-treated rats.

Inflammatory alterations in rat testis following administration of pharmacological doses of hCG, as well as the involvement of Leydig cells in these changes have been demonstrated previously $(1-4,7,8)$ The alterations observed have a temporal association with the kinetics of the cytokine response and include elevated intratesticular pressure, vascular leakage and an elevated frequency of apoptosis in spermatogonia $(3,5,6,22,23)$.

In humans, inflammatory changes following hCG pretreatment during orchidopexy in boys suffering from retentio testis have also been reported. These phenomena were found to be generally reversible, although may be persistent $(22,23)$. In rats, a similar acute inflammatory reaction in the testis can be elicited by intratesticular injections of certain pro-inflammatory stimulants, including cytokines. Thus, such local exposure to IL- $1 \beta$ but not IL- $1 \alpha$ induces a vascular response, including extravasation of leukocytes into the testicular interstitium (10). However several pro-inflammatory cytokines, most notably IL- $1 \alpha$, IL-1ra and TNF $\alpha$, are produced constitutively by the testis with no signs of inflammation. Resident testicular macrophages, which are nonactivated under intact conditions, do not appear to be involved in this constitutive production, which has been reported to occur in seminiferous tubules and Leydig cells in most studies on this question. In contrast stimulation by various pro-inflammatory agents, including endotoxin, activates testicular macrophages to initiate production of high levels of a multitude of inflammatory cytokines, which may then act as paracrine mediators of inflammation (9). Therefore, it is feasible that the inflammatory effects of hCG may be mediated by cytokines, (e.g., IL-1 $\beta$ ) released by activated resident macrophages or by cells which migrate into the testis from the bloodstream. An involvement of macrophages in the response to hCG has been implicated previously (24). This hypothesis implies that the constitutive production of IL- $1 \alpha$ does not contribute to an inflammatory reaction, which is, indeed, supported both by our finding that IL- $1 \alpha$ production in Sertoli cells is down-regulated following activation of testicular macrophages by endotoxin (9) and by the observation cited above that purified testicular IL- $1 \alpha$ and recombinant IL- $1 \alpha$ fail to induce any inflammatory response when injected directly into the testis (10). The metabolic changes observed in response to administration of endotoxin (9) were not detected in the present study. Leydig cells are the primary testicular target for activation by hCG via the LH receptor and, indeed, elimination of these cells by EDS treatment was shown to abolish

Table 2. Testosterone levels and testis weights in peripheral and testicular venous blood $8 \mathrm{~h}$ after injection of hCG (100 U) or saline into EDS-treated and control DMSO-treated rats

\begin{tabular}{lccc}
\hline & \multicolumn{2}{c}{ Serum level of testosterone $[\mathrm{ng} / \mathrm{mL}]^{*}$} & $\begin{array}{c}\text { Testis weight }[\mathrm{g}]^{*} \\
\text { (both testes) }\end{array}$ \\
\cline { 2 - 3 } Treatment & In peripheral blood & In testicular venous blood & $2.78 \pm 0.22$ \\
EDS & $<0.04$ & $<0.04$ & $3.21 \pm 0.10$ \\
EDS + hCG & $<0.04$ & $3.06 \pm 0.00$ & $2.94 \pm 0.17$ \\
DMSO & $1.22 \pm 0.54] p=0.018$ & $90.0 \pm 37.2$ \\
DMSO + hCG & $5.07 \pm 1.31] p=0.0014$ & $3.16 \pm 0.13$ \\
\hline
\end{tabular}

* Mean $\pm \operatorname{SD}(n=4)$. 


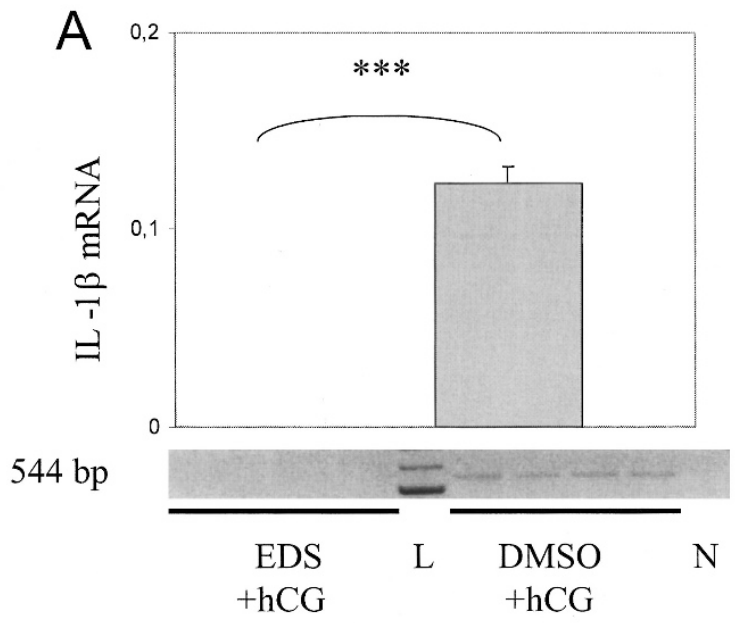

B

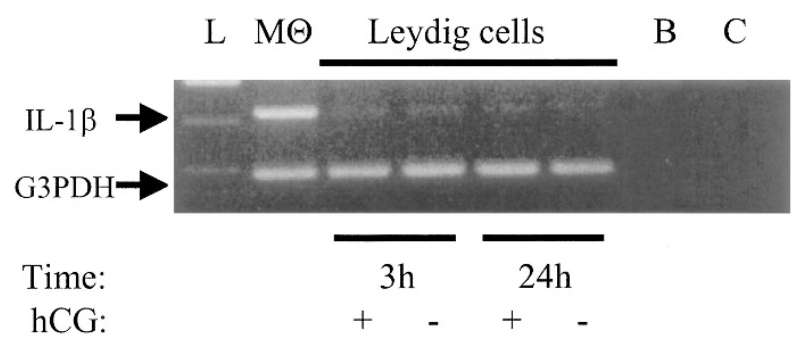

Figure 3. A. Lack of mRNA IL-1 $\beta$ induction in response to treatment of Leydig cell-depleted rat testes with hCG. Data show the level of IL-1 $\beta$ mRNA in the testes of rats pretreated with $\operatorname{EDS}(n=4)$ or solvent (DMSO; $n=4)$ and then injected with hCG. Other conditions were as described in the legend to Fig. 1. The values shown are means \pm SD of arbitrary densitometric units, normalized to the level of G3PDH mRNA after subtraction of background. *** $p<0.001$ compared with EDS-treated animals. A representative RT-PCR experiment is depicted below the bar graph. Group data defined by horizontal bar. L: size ladder. N: negative PCR control. B. Lack of induction of IL-1 $\beta$ mRNA in isolated Leydig cells incubated with hCG in vitro. Isolated Leydig cells were incubated in the presence of $10 \mathrm{ng} / \mathrm{mL}$ hCG or solvent for 3 or $24 \mathrm{~h}$ in vitro. The total RNA extracted from these cultures was then analyzed for IL- $1 \beta$ mRNA by RT-PCR (see text and Table 1 ). A weak band of IL-1 $\beta$ mRNA was barely detected in control cells and remained unchanged at both time-points after hCG incubation. M $\Phi$ depicts the level of IL- $1 \beta$ mRNA in activated macrophages (positive control). L, size ladder; B and C, RT and PCR negative controls. The housekeeping gene G3PDH was used for normalization.

the inflammatory response to hCG. Our immunohistochemical examination confirms previous observations $(15,25)$ of an intimate spatial relationship between macrophages and Leydig cells in the testis. Our detection of IL- $1 \beta$ in macrophages only, but not in Leydig cells, after administration of hCG, indicates that Leydig cells may emit juxtacrine signals which activate adjacent macrophages to begin production of pro-inflammatory cytokines. The paracrine signal suggested to be involved in this rapid activation remains to be characterized.

The physiologic significance of our present findings has yet to be investigated, but it may be suggested that this unorthodox regulation of inflammation in the testis is a component of a paracrine host defence system which protects developing germ cells from injury. Our results reveal a link between the immu-
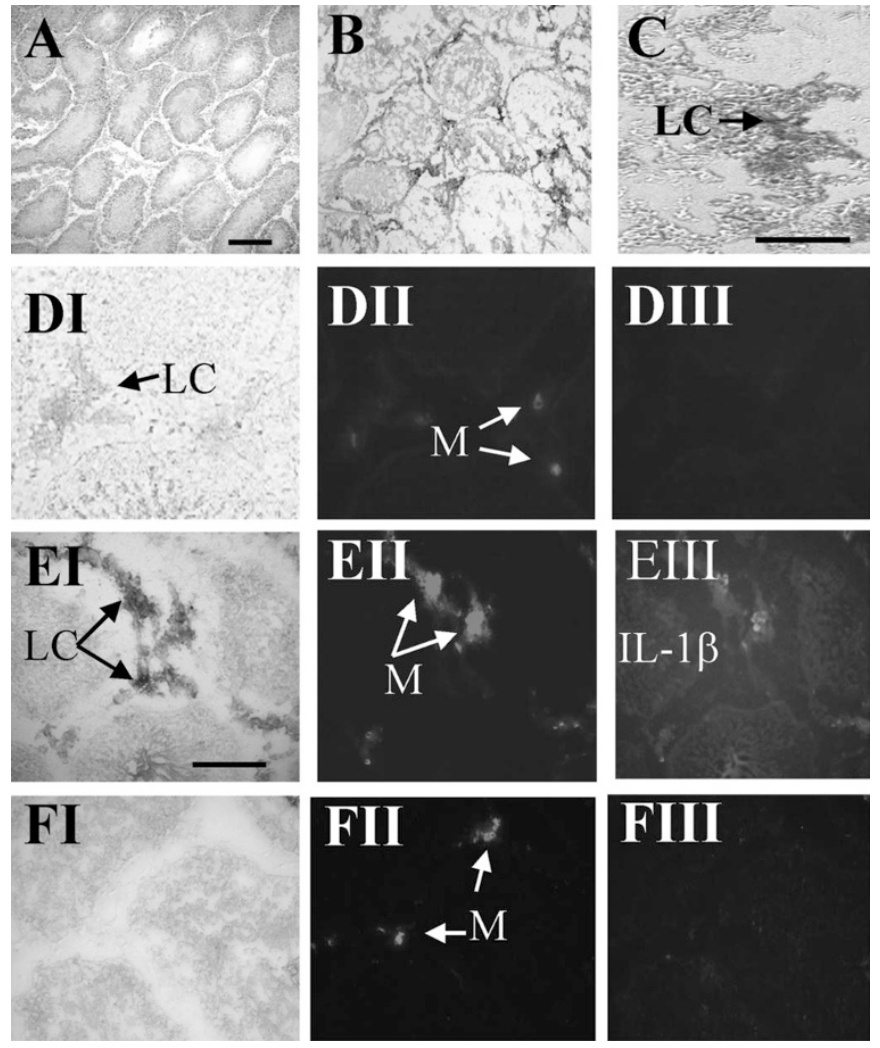

Figure 4. Micrographs of testes from treated and control rats. A. Histology of the testis of a normal control animal. Staining: Crysyl violet. Scale bar $200 \mu \mathrm{m}$. B. Staining of Leydig cells (violet) in the testis of an untreated rat. Staining: $3 \beta$-hydroxysteroid dehydrogenase. C. Immunohistochemical staining for Leydig cells (red; LC, arrows) in control testis employing primary antibodies directed against steroidogenic enzymes. Scale bar $50 \mu \mathrm{m}$. D-F. $3 \beta$-HSDstaining for Leydig cells (micrographs I; LC, violet) and immunohistochemical double-staining for macrophages (micrographs II; M, red) and IL- $1 \beta$ (micrographs III; IL- $1 \beta$, green) in the same sections from the testis of rats administered saline (D, controls), hCG (after 8 h) $(\mathbf{E})$ or EDS + hCG $(\mathbf{F})$. D. Leydig cells (I) and macrophages (II), but no expression of IL- $1 \beta$ (III) was detectable in control testes. E. Leydig cells (I), macrophages (II) and induction of IL-1 $\beta$ (III) were observed in hCG treated testes. Scale bar EI $50 \mu \mathrm{m}$. F. No Leydig cells (I), but clearly detectable macrophages (II) expressing no IL- $1 \beta$ (III) were seen in the testes of rats treated with EDS $+\mathrm{hCG}$

noinflammatory and endocrine systems and demonstrate that cytokines participate in endocrine and paracrine regulation of the testis. Clinically, repeated high pharmacological doses of hCG are used to treat boys with cryptorchidism. The mechanism of action of such treatment to cause testicular descent is unknown but one speculation may be that the resulting testicular inflammation $(6,22)$ is involved. The important question whether this cytokine-mediated testicular inflammation could adversely affect adult testis function must be addressed in future studies.

Acknowledgments. We would like to thank Ms. Yvonne Löfgren for her expert technical assistance.

\section{REFERENCES}

1. Setchell BP, Sharpe RM 1981 Effect of injected human chorionic gonadotrophin on capillary permeability, extracellular fluid volume and the flow of lymph and blood in the testes of rats. J Endocrinol 91:245-254 
2. Setchell BP, Rommerts FF 1985 The importance of the Leydig cells in the vascular response to hCG in the rat testis. Int J Androl 8:436-440

3. Bergh A, Rooth P, Widmark A, Damber JE 1987 Treatment of rats with hCG induces inflammation-like changes in the testicular microcirculation. J Reprod Fertil 79:135-143

4. Bergh A, Damber JE, Hjertkvist M 1996 Human chorionic gonadotrophin-induced testicular inflammation may be related to increased sensitivity to interleukin-1. Int J Androl 19:229-236

5. Heiskanen P, Billig H, Toppari J, Kaleva M, Arsalo A, Rapola J, Dunkel L 1996 Apoptotic cell death in the normal and cryptorchid human testis: the effect of human chorionic gonadotropin on testicular cell survival. Pediatr Res Surg 28:254-258

6. Hjertkvist M, Läckgren G, Plöen L, Bergh A 1993 Does hCG treatment induce inflammation like changes in undescended testes in boys. J Pediatr 103:892-897

7. Kerr JB, Sharpe RM 1989 Focal disruption of spermatogenesis in the testis of adult rats after a single administration of chorionic gonadotropin. Cell Tissue Res 257:163-169

8. Kaleva M, Arsalo A, Louhimo I, Rapola J, Perheentupa J, Henrikisen K, Toppari J 1996 Treatment with human chorionic gonadotrophin for cryptorchidism: clinical and histological effects. Int J Androl 19:293-298

9. Jonsson CK, Setchell BP, Martinelle N, Svechnikov K, Söder O 2001 Endotoxininduced interleukin-1 expression in testicular macrophages is accompanied by downregulation of the constitutive expression in Sertoli cells. Cytokine 14:283-288

10. Bergh A, Soder O 1990 Interleukin-1 beta but not interleukin-1 alpha, induces acute inflammation-like changes in the testicular microcirculation of adult rats. J Reprod Immunol 17:155-165

11. Sultana T, Svechnikov KV, Gustafsson K, Wahlgren A, Tham E, Weber G, Soder O 2004 Molecular identity, expression and functional analysis of interleukin-1 alpha and its isoforms in rat testis. Asian J Androl 6:149-153

12. Svechnikov K, Petersen C, Sultana T, Wahlgren A, Zetterstrom C, Colon E, Bornestaf C, Soder O 2004 The paracrine role played by interleukin-1 alpha in the testis. Curr Drug Targets Immune Endocr Metabol Disord 4:67-74

13. Sultana T, Svechnikov K, Weber G, Söder O 2000 Molecular cloning and expression of a functionally different alternative splice variant of prointerleukin- $1 \alpha$ from the rat testis. Endocrinology 141:4413-4418
14. Gustafsson K, Sultana T, Zetterström CK, Setchell BP, Siddiqui A, Weber G, Soder O 2002 Production and secretion of interleukin- $1 \alpha$ proteins by rat testis. Biochem Biophys Res Commun 297:492-497

15. Hutson JC 1993 Secretion of tumor necrosis factor alpha by testicular macrophages. J Reprod Immunol 23:63-72

16. Kern S, Robertson SA, Mau VJ, Maddocks S 1995 Cytokine secretion by macrophages in the rat testis. Biol Reprod 53:1407-1416

17. Jonsson CK, Zetterström RH, Holst M, Parvinen M, Söder O 1999 Constitutive expression of interleukin- $1 \alpha$ messenger ribonucleic acid in rat Sertoli cells is dependent upon interaction with germ cells. Endocrinology 140:3755-3761

18. Teerds KJ, De Rooij DG, Rommerts FF, Wensing CJ 1988 The regulation of the proliferation and differentiation of rat Leydig cell precursor cells after EDS administration or daily hCG treatment. J Androl 9:343-351

19. Svechnikov K, Sultana T, Söder O 2001 Age-dependent stimulation of Leydig cell steroidogenesis by interleukin-1 isoforms. Mol Cell Endocrinol 182:193-201

20. Granholm T, Fröysa B, Lundström C, Wahab A, Midtvedt T, Söder O 1992 Cytokine responsiveness in germfree and conventional NMRI mice. Cytokine 4:545-550

21. Wahab-Wahlgren A, Holst M, Ayele D, Sultana T, Parvinen M, Gustafsson K, Granholm T, Söder O 2000 Constitutive production of interleukin- $1 \alpha$ mRNA and protein in the developing rat testis. Int J Androl 23:360-365

22. Dunkel L, Taskinen S, Hovatta O, Tilly JL, Wikstrom S 1997 Germ cell apoptosis after treatment of cryptorchidism with human chorionic gonadotrophins is associated with impaired reproductive function in the adult. J Clin Invest 100:2341-2346

23. Demirbilek S, Atayurt HF, Celik N, Aydin G 1997 Does treatment with human chorionic gonadotropin induce reversible changes in undescended testes in boys? Pediatr Surg Int 12:591-594

24. Kerr JB, Sharpe RM1989 Macrophage activation enhances the human chorionic gonadotrophin-induced disruption of spermatogenesis in the rat. J Endocrinol 121:285-292

25. Hutson JC 1992 Development of cytoplasmatic digitations between Leydig cells and testicular macrophages in the rat. Cell Tissue Res 267:385-389 